\title{
Dreaming Ourselves and Aspirations Into Places of Higher Education
}

\author{
Linda Waimarie Nikora
}

\author{
Maori \& Psychology Research Unit, University of Waikato
}

\begin{abstract}
Dreams and aspirations are at the core of what higher education is about. Students and scholars alike, the world over, are engaged in the realization of dreams that bring forth new opportunities, new ways of seeing and being and of changing the world. Many Maori students dream of making a difference and see the pursuit of higher education as a way to bring their dreams into reality. Often their dreams reflect family and community aspirations bringing with it a significant burden of responsibility and obligation. And for Maori academics and researchers like me, my dreams are not too different to those of my own students except that where students pursue a pathway towards becoming relevant, academics are challenged to remain so. In this chapter, I will share some of my/our hopes and experiences and how Maori went about dreaming ourselves into the staff make up, curriculum and research activities in the School of Psychology at the University of Waikato.
\end{abstract}

Ma te Ohonga ake i taku moemoea ko te puawaitanga o nga whakaaro. (Dreams become reality when we take action.)

\section{Introduction}

$\mathrm{T}$ he development of psychology in New Zealand is said to follow a similar path to that in Australia. The 19th century saw New Zealand opened to the world of colonial politics and wars; displacement from our tribal lands, colonisation through massive migration and minoritization, followed by industrialization, and in the 20th century, the depopulation of Maori homelands through rapid urbanization. All these processes shaped the nature of dominant versus non-dominant group relationships here in New Zealand.

Contrary to the 1840 Treaty of Waitangi promises of self-determination, partnership, protection, participation, peace and respect, we found ourselves positioned as a powerless minority, stripped of and displaced from most of our lands, discriminated against in employment, housing and services, and featuring disproportionately in every negative statistic that could be found. We manifest all the symptoms of the rarely spoken of Fourth World (Moody, 1993). This picture remains true in the present day.

Social, health and education policy in New Zealand followed an agenda of assimilation (Hunn, 1961). Dominant Pakeha society expected that the sooner Maori become like their Pakeha counterparts the sooner our circumstances would improve. If anything, we continued our own agenda of wanting the best of both worlds, of being Maori and, at the same time, enjoying the benefits of what the western world had to offer (Ritchie, 1992). Since the 
1980's, policies of assimilation have been officially shelved and replaced with bicultural policies premised on the belief that we are the first people of New Zealand, that collaborative partnerships based on active participation and protection are the only way to honestly and effectively address challenges facing Maori, and indeed, the nation as a whole. While the picture in the 21st century is different, even though marginalisation and discrimination continues to persist, 'New Zealand' is still a work in progress. Sometimes we get it right, sometimes horribly wrong. Yet we persevere. When viewed against the long histories of colonization experienced by, for example the peoples of the Americas, we really haven't been engaged in this work for that long. Good things take time.

The same is true of psychology. Psychology is a young discipline. With our roots in philosophy, psychology in New Zealand began as a colonial off shoot initially influenced by psychology in the UK and Europe, and later by the USA. And there were two dominant themes in this development. The first might be characterized by the motivation to help relieve suffering. And this is the aspect of psychology that I and my students are the most interested in. They are motivated by a concern to reduce pain and distress and social equity goals of ridding our society of racism, discrimination, poverty, addiction, and the like.

The second development theme relates to the want to establish an identity independent from the British motherland and to compete on the world scene. Here psychology in New Zealand has developed as a theoretical scholarly academic subject concerned with being a reputable 'science'. Invariably, this means competing according to majority group rules, that is, rules and trends set by organizations like the British and American Psychological Associations. These are but a few aspects of our colonial history that have shaped the present nature and form of New Zealand psychology today.

So, given this colonial history and neocolonial tensions, how has psychology engaged Maori over time? How has it supported our hopes and aspirations? How has it relieved suffering? How have we dreamed ourselves into the discipline as academics and researchers?

\section{Western psychological engagement of Maori}

Up until the 1980's, with the exception of a rare few, psychology's stance in relation to Maori was typically one of disinterest. The most active and engaged interest emerged out of Victoria University in Wellington while under the watch of Professor Ernest Beaglehole. Amongst the mental health professionals that he nurtured (nurses and clinicians) he also grew a generation of psychologists, all Pakeha, who completed graduate theses on topics of interest to those in the culture and personality movement. These tended to be qualitative ethnographic studies of Maori communities undergoing rapid change. While these studies have been rightfully criticized because they reflected the persistent assimilationist agenda of policy makers and the government of the day, they must also be celebrated and valued for their deep descriptive rich data and the window they presented on Maori life in the 1950's and 60's. Who would have thought that the township known as 'Kowhai', then described as devoid of Maori leadership, would become the site of the first tribal university now known as Te Wharewananga o Raukawa.

It is from the Beaglehole school of academics and scholarship that James Ritchie, with his 'no research without action, no action without research' mantra emerged (Ritchie, 1992) to become the founding chair at my own university, the University of Waikato in 1965. More of him later. 
The first graduate theses and research projects by Maori in psychology began to emerge in the late 1960's. In (1968), John Mitchell published his efforts on the senses followed in (1972) by Averil Herbert's work on job satisfaction, and in 1974, by Donna Awatere (1974) with her work on ethnic awareness. Reflecting on her experiences as a student, Donna Awatere noted...

So I have to say they failed me - can you believe that! I did what I believed was the genesis of some really great work about what Maori culture was all about and about the therapeutic roles that we had in our culture. Failing that paper really got my back up. I simply learned that if you want to pass you just give them what they want. Don't be clever. Don't be smart. Don't try to develop new models. If that's what they say, that's what they get back. Except, there is a little bit of your soul that goes with it every time you make those compromises. It's like a wife that gets beaten. Every time you say “...yes, darling I will have you back” you lose a little bit of your soul. I think that's what happened to me. (Awatere-Huata, 2000, p13)

While this still remains as an experience for Maori students studying psychology today, the context has changed with more opportunities for Maori students to be in command of their own research directions that give expression to indigenous perspectives and ways of being in and shaping the world. Ngahuia Te Awekotuku's (1981) PhD thesis is an example of this. She turned her ethnographic gaze to her own community to test the premise that tourism had a negative socio-cultural impact on her tribal group, Te Arawa. Hers was the first 'at home' $\mathrm{PhD}$ in psychology completed by a Maori women. On the heels of Te Awekotuku's work, in (1983), was that of Christina Lyndon, out of Auckland, who made an important and significant contribution in a study of Maori beliefs and the diagnosis of mental illness among Maori. These two studies were the wedge that subsequent waves of Maori students in psychology needed. They cleared a pathway for later generations of psychology students to complete research as 'insiders' and participants within their own worlds. Unlike earlier graduates, there were now precedents that could be follow and work that students of today could find.

\section{The University of Waikato}

Since the 1970's, the University of Waikato has attracted significant numbers of Maori students from a predominantly Maori catchment area. They came initially to train as teachers at the adjoining training college, and later, were attracted to pursue Maori studies mostly because of the presence of Maori tribal leaders like Te Kotahi Mahuta of Waikato/Tainui and Te Rangianiwaniwa John Rangihau of Tuhoe who the university employed in the 1970's as staff of the Centre for Maori Studies and Research (Ritchie, 1992). The likes of Timoti Karetu, Wharehuia Milroy and Hirini Melbourne were to follow shortly after them and established the Maori Studies Department.

In the mid 1980's, when I began my studies, there were about 300 Maori students of about 3000 students attending the growing and expanding institution. Most Maori were pursuing degrees in Maori studies, Education, Social Science and Management Studies. There were few, if any, pursuing science degrees. We all knew each other and we were a tight knit community participating in each other's lives, struggles, achievements and disappointments. In 1988, every Maori student who graduated with an undergraduate degree that year joined 
together to attend the graduation ceremony and to spend an evening with family and friends celebrating. There were eight of us. And I was the lone major in psychology.

In 1989, I joined the staff of psychology as a young Maori academic with Stephanie Palmer of Harataunga, Coromandel. We both occupied junior lecturer positions or training positions that allowed us time to advance our graduate studies. As mentioned earlier, the psychology department at Waikato was first established in 1965, and Professor James Ritchie was the foundational Chair. He proposed an interdisciplinary approach in which psychology was to be part of a broad social science programme. This was to be a 'useful' science that strongly emphasised social research, the servicing and solution of social and personal problems as well as the psychology of mental health, child development, of work, counselling, family psychology and policy. While some of these ideals have faded over the years, psychology at Waikato has maintained the original vision of being an applied discipline, strongly committed to addressing real world problems.

With such a vision and the strong leadership of Professor Ritchie, psychology at Waikato has had a strong tradition of taking Maori issues seriously. Well, more seriously than other institutions and disciplines. We were the first school of psychology in the country to appoint a Maori academic (Linda Waimarie Nikora) to a continuing position and now include among our staff of about 21 academics, 6 Maori in continuing positions (Professor (1.0 FTE), Associate Professor (1.0), Senior Lecturer (1.0), Lecturer (3.0FTE)) and a research officer 0.5FTE and Senior Maori Tutor (0.5FTE). We aim to be the school of choice for Maori wanting to study psychology and about $25 \%$ of our undergraduate students and $20 \%$ of our graduate students identify as Maori. We have the largest participation of Māori at all levels of learning among psychology departments in New Zealand universities. More important, though, is the growing body of knowledge that Maori graduates are contributing to the teaching and practice of psychology.

\section{Psychology@Waikato}

Psychology is a peculiar subject. It's one that is sandwiched between the 'soft' and 'hard' sciences with the experimental method a point of contention. Some see it as a practice of dissembling, where the researcher hides their presence as a contributing variable, while others view it as one research method amongst many available to answer research questions. And that fact makes our discipline bit bipolar! For example, psychology is taught variously around the globe and often reflects the biases of those who teach psychology rather than being a coherent programme of study in the best interests of students and the community. What makes psychology at Waikato different is its appreciation of culture, an emphasis on the indigenous, and most significantly, the very real presence of Maori students.

In the early 1990's, there was a Maori student called Keri Lawson. She had returned to university as a mature student and industriously pursued her first and second year programme in psychology. In her third year, she became increasingly aware of the significant numbers of Maori students enrolling in first and second year papers and asked the paper coordinators if she could come into their classes to advertise an offer of academic support, free of charge, directly to Maori students. They agreed, and this was the genesis of what we now call the kaupapa Maori tutorial programme. Kaupapa Maori tutorials are tutorials that are run, on the whole, by a Maori tutor, for Maori students, in a way that is responsive to their needs and in a way that they feel most comfortable. Other students may attend but they participate on the understanding that this is the way that things are done - in a Maori way. While Maori staff 
can give advice on appropriate tutors, the final decision is left over to course coordinators as to who they select as kaupapa Maori tutors in their papers. The tutors are paid out of the budget available to each coordinator for tutorials, rather than coming from a 'special fund'. In this way, course coordinators take responsibility and have a vehicle for actively supporting Maori students, rather than that responsibility resting solely on Maori staff.

The department also employs a Senior Maori tutor (0.5) to help support Maori tutors; to provide direct academic support to Maori students; and to work with staff to follow up specific Maori students. From my perspective, it is vital that this kind of support is provided to first year students as they try to understand the language and rules of psychology.

Developing academic literacy is vital - simple skills like, attending lectures, knowing how to use a library, how best to take notes, how to prepare for exams, what to do if you have a crisis when an assignment is due - these are essential skills to develop if a student is to survive psychology. Added to the support provided via the in-course tutorial programme, the Senior Maori tutor runs 'wananga' or study groups to prepare students for tests and assignments. These have always been well attended. Sometimes they are a one hour long session or a whole weekend where students live and study together. What amazes me about this programme is the fellowship that develops between students, something that can mean the difference between a student persevering or dropping out.

Kaupapa Maori tutorials and academic support are now considered an ordinary and unremarkable feature of what we do in psychology at Waikato. But this was not always the case. In the 1990's, I had students, staff, the Head of Department, Deans, and the Race Relations Office all banging on my door wanting explanations. We have had to fight off regular complaints from students that this initiative favours and advantages Maori; that Maori students collaborating on assignments and test preparation are cheating; that it's separatist, unfair, exclusionary - the list goes on. I am happy to say though, that I think these complaints are both unwarranted and largely in the past.

\section{The Maori \& Psychology Research Unit}

When I first suggested to my colleagues 20 years ago that they begin to include Maori material in their courses, their response was, 'give us the journal article and we'll include it', 'find us the reading material and we'll have students read it'. Having struggled to compile relevant literature for students in those courses I taught, I knew this to be a difficult but not impossible task. Instead of sinking myself in the library in search of material, I returned to my office and commissioned a survey of staff (Masters \& Levy, 1995) to see why they were not writing such journal articles and reading material themselves. The results of that survey told me that: 1) staff did not feel adequately confident to engage with Maori; and 2) they were afraid of what was then perceived of as a 'no go zone' for non-Maori. The results of this evaluation became the genesis of the Maori and Psychology Research Unit (MPRU) its mission being to conduct Maori focused research on concerns relevant to Maori. It was to act as a resource for staff and students wanting to enter into collaborative research partnerships with Maori researchers and communities to do research. Since its establishment in 1996, we have conducted research on a wide range of topics (parenting, smoking cessation, epilepsy, domestic violence, Maori cultural concepts, bloke culture, media representations, migration, homelessness, poverty, medications and death rituals) and collaborated with colleagues here in my own school, in other disciplines and at other institutions, nationally and internationally. The research output has been significant and satisfying. When compared with other research units across our school the MPRU has the highest income from external grants, we repeatedly 
win very prestigious grants and prizes, and increasingly, are diversifying the range of grant agencies that we win grants from.

With a brief to also disseminate Maori psychological knowledge, the MPRU has accumulated almost two decades of research reports, graduate thesis work and papers from symposia and conferences that students and staff have attended or organized. ${ }^{1}$ This represents a significant amount of knowledge and resources available to students and staff for teaching and practice.

I celebrate each research output achieved by staff of the MPRU. This is how we write our dreams into reality and how we come to have a presence in the life of the academy and to make an important contribution to growing the literature about and for us as Maori. But what of the future? Are we heading toward transforming psychology in New Zealand in an enduring way or are we simply polishing the margins?

\section{Future directions}

Much of the change that has occurred at Waikato can be described as polishing the margins. We have just tweaked the edges and are yet to change the substance of what we do in any enduring or permanent way. Nevertheless, James Ritchie did give us a head start, as have Maori graduate students who have contributed to the small but growing body of Maori psychological knowledge. There are also those beyond our university whose work we come to know through searching the web, participating in conferences or collaborative research endeavours. And we need more of it, much more of it! And we need to be strategic and smart. As Levy (2007) pointed out, much of the research in this area is ad hoc and often takes place in isolation leading to a field grown according to the aspirations and interests of researchers and that lacks coherency. There is a task here to synergize the incremental gains that have been made to form a clear foundation for future development, and this demands more than a mere literature review. These contributions need to be bought together and theorised in a synergistic fashion to consolidate the field so that new gains can be made in areas where there are gaps, or where a 'spring board' is identified to launch a unique pathway towards new knowledge.

One way of realising a coherent body of knowledge is through the writing of text books to form a foundation for teaching and research. The importance of this is not to be under estimated. Students become what they read and learn. If our students continue to be fed the same biased and skewed material that my generation grew up with, nothing will change. We will have failed in our duty to realise an indigenous psychology, of and for our context here, in New Zealand and for its peoples. Text book writing is not an easy task. But neither is it impossible. It will demand time and resources, but there are now enough Maori academics, writers and researchers to spread the load and to realise this task in the not too distant future.

The last comment I wish to make relates to an attitudinal disposition. As the number of Maori on staff in psychology at different universities increases, their interests and specialisations of will diversify across the discipline. Presently, there is quite a nice balance of Maori staff in the social and clinical psychology. But this needs to spread further into other areas, for example, behavioural, physiological, neurological and organisational. All these sub-fields of psychology have knowledge and applications to relieve suffering and to make a difference in the lives of Maori people. Yet, will Maori staff appointments in these areas result in research

\footnotetext{
${ }^{1}$ See http://researchcommons.waikato.ac.nz/handle/10289/3 for MPRU publications
} 
of, with and for Maori? Much will depend on the motivation, attitude and commitment they bring to serving the interests of Maori people. I look forward to the emergence of their work in the future.

\section{Works Cited}

Awatere-Huata, D. (2000). Challenges to Psychology in Aotearoa. In L. W. Nikora (Ed.), Cultural Justice and Ethics : Proceedings of a Symposium Held at the Annual Conference of the New Zealand Psychological Society, University of Victoria, Wellington, 23-24 August 1993 (Rev ed., pp. 13-20). Wellington, New Zealand: National Standing Committee on Bicultural Issues.

Awatere-Huata, D. (1974). The Development of Ethnic Awareness and Ethnic Attitudes in a Sample of Auckland Primary School Children. MA Psychology, University of Auckland, Auckland, New Zealand.

Herbert, A. M. L. (1972). A Job Satisfaction Survey in Which Some Happy and Some NotSo-Happy People Are Found and Their Feelings Recorded. MA Psychology, Canterbury University, Christchurch, New Zealand.

Hunn, J. K. (1961). Report of Maori Affairs. Wellington, New Zealand.: Government Printer.

Levy, M. P. (2007). Indigenous Psychology in Aotearoa: Realising Maori Aspirations. PhD Psychology. University of Waikato, Hamilton, New Zealand

Lyndon, C. (1983). Beliefs in Tapu, Mate Maori and Makutu and the Relevance of These Beliefs to the Diagnosis of Mental Illness Amongst the Maori. MA Psychology, Auckland University, Auckland, New Zealand.

Masters, B., \& Levy, M. (1995). An Evaluation of Kaupapa Maori within the Psychology Department at the University of Waikato. Hamilton, New Zealand: Maori \& Psychology Research Unit, University of Waikato.

Mitchell, M. J., \& Gregson, M. (1968). Stimulus Specificity and Thresholds of the Chemical Senses. Christchurch, New Zealand: Dept. of Psychology and Sociology, University of Canterbury.

Moody, R. (1993). The Indigenous Voice : Visions and Realities (Rev., 2nd ed.). Utrecht, Netherlands: International Books.

Ritchie, J. E. (1992). Becoming Bicultural. Thorndon, Wellington, New Zealand: Huia Publishers : Daphne Brasell Associates.

Sinha, D. (1997). Indigenizing psychology. In J.W. Berry, Y. Poortinga, \& J. Pandey (Eds.), Handbook of cross-cultural psychology. Vol. 1: Theory and method (pp.129-169). Boston, Massachusetts: Allyn \& Bacon. 
etropic 13.1 (2014): Leadership in Indigenous Research Special Issue | 8

Te Awekotuku, N. (1981). The Sociocultural Impact of Tourism on the Te Arawa People of Rotorua. New Zealand. PhD Psychology. University of Waikato, Hamilton, New Zealand. 